\title{
Immediate Implant Placement: Current Concepts
}

\author{
Dr. Bhageshwar Dhami, ${ }^{1}$ Dr. Priti Shrestha, ${ }^{2}$ Dr. Sujaya Gupta, ${ }^{1}$ Dr. Nashib Pandey ${ }^{1}$ \\ ${ }^{1}$ Department of Periodontics, Kantipur Dental College, Kathmandu, Nepal; \\ ${ }^{2}$ Department of Periodontics, KIST Medical College, Kathmandu, Nepal.
}

\begin{abstract}
Immediate implants following extraction has become an increasingly popular strategy to preserve bone and reduce treatment duration. This technique also improves aesthetics by preserving the soft tissues. Immediate implant placement is technically challenging and should only be undertaken by clinicians with considerable experience in implant dentistry, both surgically and prosthetically. The purpose of this article is to provide a general review about immediate implant placements and to summarise various aspects in which this technique can be indicated.

Keywords: Dental implant, extraction, jumping distance, immediate placement, primary stability.
\end{abstract}

\section{INTRODUCTION}

Replacement of missing teeth using dental implants has proven to be a popular, successful and predictable treatment procedure. Over the years, different implant placement protocols have evolved in order to achieve easier and quicker surgical techniques. Immediate placement of a dental implant in an extraction socket was initially described more than 30 years ago by Schulte and Heimke in $1976 .{ }^{1}$ Lazzara $^{2}$ later in 1989 reintroduced the method of immediate implant placement into fresh extraction sockets with three case reports.

Since then, the percentage of partially edentulous patients in implant dentistry has significantly increased. Today, the immediate implant placements predominate in regular dental practice, particularly the single missing tooth $\mathrm{h}^{3,4}$ as the healing period of about six months post extraction prior to implant placement is not an attractive option any more to patients. Thus, the timing of implant placement has become an important issue in implant dentistry.

\section{CLASSIFICATION OF IMPLANT PLACEMENT}

Wilson and Weber ${ }^{5}$ in 1993 used the terms Immediate, Recent and Delayed. Matureto describe the timing of implant placement in relation to soft tissue healing and

\section{Correspondence:}

Dr. Bhageshwar Dhami,

Department of Periodontics, Kantipur Dental College,

Kathmandu, Nepal.

email:dhamibhagesh@gmail.com

\section{Citation}

Dhami B, Shrestha P, Gupta S, Pandey N. Immediate Implant Placement: Current Concepts. J Nepal Soc Perio Oral Implantol. 2019;3(5):18-24 the predictability of guided-bone regeneration procedures. Mayfield et al used the terms, i. Immediate- Time interval of zero week after extraction, ii. Delayed - Time interval of six to 10 weeks after extraction, and iii. Late- Time interval of six months or more extraction. ${ }^{6}$

Hammerle et $\mathrm{al}^{7}$ (2004) classified according to Timing of implant placement into:

Type I: implant placement in fresh extraction socket

Type II: implant placement after soft tissue coverage (4-8 weeks)

Type III: implant placement after radiographic bone fill (12-16 weeks)

Type I: implant placement in healed sockets (> 16 weeks)

Garber et $\mathrm{al}^{8}$ (2007) based on timing of tooth extraction and implant placement classified into:

Class I: Extraction, with immediate implant placement directly into the extraction socket via (a) "Incisionless" implant placement, and (b) Raising of a mucoperiosteal flap. Placement of the implant into the extraction socket concomitant with either, i. Osseous augmentation or Guided bone regeneration (GBR) or ii. Connective tissue or allograft.

Class II: Early implant placement. The implant is placed after extraction, and soft tissues are allowed to heal for six to eight weeks. GBR can be performed at the time of extraction and/or at the time of implant placement.

Class III: Delayed implant placement. The implant is placed a minimum of four to six months after extraction, with preservation of alveolar ridge using grafting techniques and/or GBR, either at the time of extraction or concomitant with implant placement. Soft tissue reconstruction in these cases will be invariably required. 
According to both the osseous and soft tissue levels of the potential site at the time of extraction, Garber classified into:

\begin{tabular}{|l|l|l|l|l|}
\hline Class & Buccal Bone and Gingival Biotype & Viable Implant Placement Technique & $\begin{array}{l}\text { Expected Results of } \\
\text { Immediate Implant } \\
\text { Placement }\end{array}$ & $\begin{array}{l}\text { Indication For } \\
\text { Immediate Implant } \\
\text { Placement }\end{array}$ \\
\hline Class I & Intact with thick gingival biotype & $\begin{array}{l}\text { Immediate without flap reflection } \\
\text { (incisionless) }\end{array}$ & Optimal & Yes \\
\hline Class II & $\begin{array}{l}\text { Intact with thin more scalloped } \\
\text { gingival biotype }\end{array}$ & $\begin{array}{l}\text { Immediate with connective tissue } \\
\text { graft or staged connective tissue graft }\end{array}$ & Good & Yes \\
\hline Class III & $\begin{array}{l}\text { Deficient, but implant placement } \\
\text { possible in remaining alveolar } \\
\text { housing of extraction socket }\end{array}$ & $\begin{array}{l}\text { Immediate with simultaneous guided } \\
\text { bone regeneration and connective } \\
\text { tissue graft or followed by staged } \\
\text { connective tissue graft }\end{array}$ & Acceptable & Limited \\
\hline Class IV & $\begin{array}{l}\text { Deficient and implant may } \\
\text { deviate from alveolar housing }\end{array}$ & Delayed & Unacceptable & No \\
\hline
\end{tabular}

The four treatment options for post-extraction implant placement as defined by the International Team for Implantology (ITI) in two ITI Consensus Conferences (2003 and 2008$)^{9}$ are:

1. Immediate implant placement: same day of extraction

2. Early implant placement with soft tissue healing:4-8 weeks

3. Early implant placement with partial bone healing:12-16 weeks

4. Late implant placement with complete bone healing: $>6$ months

Immediate implant placement may be defined as implant placement immediately following tooth extraction and as a part of the same surgical procedure, or as implant placement immediately following extraction of a tooth which must be combined in most patients with a bone grafting technique to eliminate peri-implant bone defects. ${ }^{10}$

An abundance of literature supports the placement of immediate implants and almost all studies report high survival rates of immediate implants from 92-100\% however case selection is necessary. ${ }^{11}$

\section{POST-EXTRACTION RIDGE RESORPTION}

\section{Dimensional changes of hard tissue ${ }^{12}$}

1. The inflammatory phase: It starts with the formation of the blood clot. Inflammatory cells migrate to the site to "clean" it before the formation of a new tissue in 2 to 3 days. After 4 to 5 days inflammatory cells, vascular sprouts and immature fibroblasts form a granulation tissue which is gradually replaced with provisional connective tissue matrix that is rich in collagen fibers and cells.

2. The proliferative phase: There is an appearance of osteoid calcification, which begins at the base and at the periphery of the socket. The bone matrix appears very early towards the 2nd week of healing and bone filling occurs between five to 10 weeks and it is complete after 16 weeks. A complete epithelial closure of the socket takes place after four to five weeks. ${ }^{13}$

3. Bone modeling and remodelling phase: Bone modeling is characterised by a change in the shape and architecture of the bone. The healing process after tooth extraction is characterised by resorption, which can cause complications during the implant restoration. ${ }^{14}$ When ridge preservation procedure has not been performed, a mean bone resorption of $1-2 \mathrm{~mm}$ in the vertical direction and 4-5 $\mathrm{mm}$ in the horizontal direction were observed. Resorption is more important at the buccal than lingual or palatal aspect. It is more pronounced in the molar region, but it remains critical in the anterior region because of the aesthetic requirement. The most bone resorption occurred during the first year after extraction, of which $2 / 3$ rd were observed during the first three months. ${ }^{15}$

\section{Dimensional changes of soft tissue}

Immediate implant placement may cause mild gingival recession $^{16,17}$ and regardless of the periodontal biotype, a soft tissue defect (in width) is noted. Marginal tissue recession is more evident on implants which are positioned bucally and on gingiva with thin biotype. ${ }^{18}$ Immediate implants placed along with connective tissue grafts have shown less than $1 \mathrm{~mm}$ of marginal tissue discrepancy. ${ }^{19}$ However, a recent systematic review by Lee et al, have not found any significant advantage of using connective tissue grafts towards reducing gingival recession. ${ }^{20}$ Hence, more studies are required to advocate the combined use of soft tissue grafts and immediate implants.

Canullo et $\mathrm{al}^{21}$ studied the use of platform switch implants in context of marginal tissue recession. They reported significantly less recession when platform switch implants 
were used. It has been observed that placement of provisional crowns on immediately placed implants may not only improve preservation of buccal bone, but also improve aesthetics by reducing gingival recession. ${ }^{22,23}$

\section{ADVANTAGES ${ }^{24,25}$}

- Reduction in the number of surgical interventions

- Treatment duration is reduced

- Bone width and height of the alveolar bone is preserved, enabling maximal utilisation of bone-implant surface area

- Ideal orientation of the implant can be achieved

- Preservation of bone at the extraction site

- $\quad$ Soft tissue aesthetics can be maintained

- Better patient acceptance

\section{DISADVANTAGES ${ }^{26,27}$}

- Risk of partial alveolar bone resorption due to a pathologic process or to a traumatic damage during the extraction

- Difficulty to achieve a primary stability

- Gap between implant surface and socket wall

- Additional cost in cases of guided bone regeneration

- Difficulty to predict the final position of the implant

- Difficulty to achieve a complete closure of the implant site

- $\quad$ Need to raise a flap in order to cover the implant if two stage procedures is preferred

\section{INDICATIONS $^{28}$}

- Tooth extraction done due to

- Trauma

- $\quad$ Endodontic causes

- Root fracture/ resorption/ perforation

- Unfavourable crown to root ratio (not due to periodontal loss)

- Bony walls of alveolus that are still intact

- Intact facial bone wall with a thick wall phenotype (>1 $\mathrm{mm}$ )

- Thick gingival biotype

- Sufficient bone volume apically and palatally of the extracted root to allow a correct three dimensional implant positioning with good primary stability

\section{CONTRAINDICATIONS ${ }^{29}$}

- Presence of active infection

- insufficient bone $(<3 \mathrm{~mm})$ beyond the tooth socket apex for initial implant stability

- $\quad$ wide and/or long gingival recession

- Proximity to vital anatomic structures

\section{IMMEDIATE IMPLANTS IN THE AESTHETIC ZONE}

Based on the current evidence, ${ }^{24,29}$ it can be said that the thickness and integrity of buccal bone plate and gingival biotype are the critical factors that play a pivotal role in the success of immediate implants. An inter-implant distance of three $\mathrm{mm}$ is preferred for papilla formation and the presence of an average of two mm buccal plate and a minimum of one mm is ideal to avoid soft tissue recession. While following immediate implant protocol, buccal position of the implants should be avoided. Implants should be placed slightly palatally/ lingually. Thicker gingival biotype is more favourable. Gingiva with high scalloping can lead to an increased risk of recession. Location of interproximal bone influence the overall soft tissue architecture. Minimal trauma in tooth extraction can be carried out either with Piezosurgery ot Periotomes with minimal mucoperiosteal flap and soft tissue trauma. Self-tapping implants enhance primary stability which compress the alveolar bone as the implant is inserted. The gap of at least two mm between the implant and the internal surface of the facial bone wall should be filled with bone substitutes which have a low resorption rate. ${ }^{30}$ In order to compensate for the expected vertical resorption, implant should be placed at least one $\mathrm{mm}$ apical to buccal ridge or 2-3 $\mathrm{mm}$ from gingival margin. ${ }^{31}$ Primary implant stability is another important factor which requires engaging the lateral walls of the socket without changing the original socket depth, or by engaging bone apical to the original socket dimensions. A tapered design implant will be beneficial for immediate implant placement. In addition, factors such as use of platform switch implants, flapless surgical approach, simultaneous placement of connective tissue grafts and immediate provisional restorations may be considered. Success with immediate implant protocol in aesthetic area requires advanced surgical skills, ideal extraction socket conditions and knowledge of local anatomy. It is recommended that in absence of ideal circumstances, other implant timing protocols that have provided excellent clinical outcomes with regards to soft and hard tissues be followed. ${ }^{32}$

Placement of a wide diameter or a wide platform implants should be avoided in the aesthetic zone sites. Usually, maxillary central incisors, cuspids, and premolars and also mandibular cuspids and premolars are treated with implants having a diameter of approximately four $\mathrm{mm}$. Implants in the region of lateral incisors and mandibular incisors should not to exceed a diameter of $3.5 \mathrm{~mm}^{33}$ The clinical guidelines for immediate implant placement protocol are summarised in Table 1. 
Table 1: Clinical guidelines for aesthetic outcomes.

- Thick and intact buccal bone wall

- Thick gingival biotype

- Minimal trauma in tooth extraction

- Presence of at least three socket walls-ideally four walls

- Implant design

- Implant shoulder should be placed 2-3 mm apical to anticipated gingival margin

- Primary implant stability

- Slight palatal/lingual positioning of implant

- $\quad$ Fill the gap

\section{IMMEDIATE IMPLANTS IN THE POSTERIOR REGION}

In the posterior region, implant placement in the root socket can lead to a non-ideal restorative position. This may result in mechanical overload and failure of the implant. In addition, the resulting structure of the restoration may render oral hygiene more difficult, which enhances the risk for periimplantitis. To avoid these potential problems, studies ${ }^{29}$ have suggested placing the implant into the inter-radicular bone and augmenting the remaining socket with graft material and a membrane. Although there is limited data on the the long-term performance in published literature, ${ }^{29,34}$ the use of immediate molar implants appears to be a valid treatment in the hands of skilled clinicians. Given the complexity of the procedure, clinicians should follow strict guidelines to minimise the risk of complications/failures.

Based on the current literature, the following guidelines are recommended for the implant placement in the posterior region (Table 2): ${ }^{34}$

Table 2: Clinical guidelines for immediate implant placement in posterior region.

- Patient should be non-smokers

- A pre-operative Cone-beam computed tomogram scan to minimise risk especially in mandible

- Thick gingival biotype and adequate keratinised tissue width ( $\geq 2 \mathrm{~mm}$ )

- Atraumatic extraction with flap-less surgery if feasible

- Only sites with intact socket walls after extraction

- Osteotomy preparation will vary with socket type

- Implants to be submerged (up to $2 \mathrm{~mm}$ ) below the buccal bone crest if crestal buccal bone is thin $(<2$ $\mathrm{mm})$.

- $\quad$ Thin buccal plate $(<2 \mathrm{~mm})$ may require more lingual placement of the implant with gap grafting and/or buccal overgrafting

- Gaps between implant and socket walls generally grafted if $\geq 2 \mathrm{~mm}$ in width

- Xenograft or mineralised allograft preferred

- Initial implant stability should be established

- $\quad$ Submerged healing if primary stability is less than 25 and resonance frequency value is less than 60

\section{SOCKET PRESERVATION}

Most extractions are done with no regard for maintaining the alveolar ridge. Whether due to caries, trauma or advanced periodontal disease, tooth extraction and subsequent healing of the socket commonly result in osseous deformities of the alveolar ridge, including reduced height and reduced width of the residual ridge. ${ }^{35}$ There is more substantial horizontal bone loss than vertical bone loss after tooth extraction. The buccal aspect generally displays more resorption than the lingual/ palatal aspect. There is an observed resorption pattern of rapid reduction in the first 3-6 months, followed by gradual reduction thereafter, throughout life. Socket preservation may serve to improve the aesthetic and functional outcomes. Socket preservation techniques are beneficial in preserving alveolar hard and soft tissues. When intact or nearly intact extraction sockets are present, an immediate implant placement technique offers the advantages of the socket preservation technique and reduces the time required to achieve a final restoration.

Socket shield technique: In 2010, Hürzeler et al introduced a new method, the socket shield technique, in which a partial root fragment was retained around an immediately placed implant with the aim of avoiding tissue alterations after tooth extraction. ${ }^{36}$ Histologic evaluation in beagle dogs showed no resorption of the root fragment and new cementum formed on the implant surface. Their clinical case demonstrated excellent buccal tissue preservation and clinically successful osseointegration of the implant. Joseph and Kitichai reported an alternative approach in a case utilising a retained proximal root fragment to maintain the inter-implant papilla. ${ }^{37}$

\section{PROVISIONALISATION}

Fabricating provisional restoration allows us to have an idea for definitive crown as similar to the natural tooth that was present earlier. Moreover, it also helps to reform the interdental papilla between the implant supported crown and the natural tooth. Light-cured composite can be used at the base of the provisional restoration to create an emergence profile as it causes less soft tissue irritation. Elimination of the auto polymerised acrylic resin monomer is responsible for soft tissue irritation with the acrylic resins. ${ }^{38,39}$ The provisional restoration should be designed so as to minimize pressure on the surgical site, optimize space for the gingival tissues, and control occlusal loading of the implant during the initial stages of osseointegration..$^{40}$

\section{JUMPING DISTANCE}

The space between the implant periphery and surrounding bone is called the gap or jumping distance. ${ }^{41}$ The gap consists of two dimensions: Horizontal defect width and vertical 
defect height. The term "jumping distance" refers to the ability of bone to bridge the horizontal gap and fill the void. The main objective of immediate implant placement is to provide an osseointegrated fixture suitable for an aesthetic and functional restoration. Bone fill in the gap between the implant and the peripheral bone is important. The buccal aspect of an implant is of great concern, especially in the aesthetic zone, because the buccal bony plate is usually thin ${ }^{42,43}$ and its resorption can result in soft tissue recession. ${ }^{44}$ The objective of the surgical management of the buccal gap is optimal bone fill in the gap, most coronal level of bone-to-implant contact and the least amount of buccal bone loss and soft-tissue recession. ${ }^{45}$

The initial bone wall thickness before the immediate implantation associated with guided bone regeneration may influence bone formation. ${ }^{46}$ Intrabony defects are partially or completely remodeled (healed) without further intervention. ${ }^{47}$ A lateral gap of 1 to $1.25 \mathrm{~mm}$ could heal spontaneously with formation of a new bone, however the addition of a membrane would not improve the healing process. ${ }^{47}$ In cases of severe defect, the choice between an immediate implantation associated with guided bone regeneration or a delayed implantation should be evaluated. The decision criteria for the surgeon are related to the possibility of complete site closure and if not obtained, the risk of membrane exposure may lead to graft complications and implant failure. ${ }^{48}$ The filling of the gap remained between the implant and the buccal bone plate with autogenous bone graft could be resorbed. ${ }^{49}$ Bovine hydroxyapatite material could reduce bone resorption in the buccal aspect of the implant. ${ }^{50}$ Partial bone formation occurs when space is filled by Beta-TCP, however, no scientific evidence of superiority of one material over another has been yet established. ${ }^{51}$ Animal experiments with injection of mesenchymal cells of the umbilical cord in the case of a severe peri-implant bone defect have shown their ability to promote formation of new bone..$^{52}$

\section{TECHNIQUES USED IN IMMEDIATE IMPLANT PLACEMENT SURGERY}

It is always safe to start with a pilot drill, as there is a risk to slip into the socket and perforate the buccal bone plate because of the hardness of the palatal wall. To avoid this problem, two techniques can be used: ${ }^{53}$

1. Round bur technique: The drilling is initiated with a small round bur about $1 / 3$ of the apex on the palatal wall of the socket. The drilling is then carried out keeping a palatal direction with respect to the tooth axis. This technique is indicated in cases of immediate implantation without or with minimal tissue loss (Figure 1).
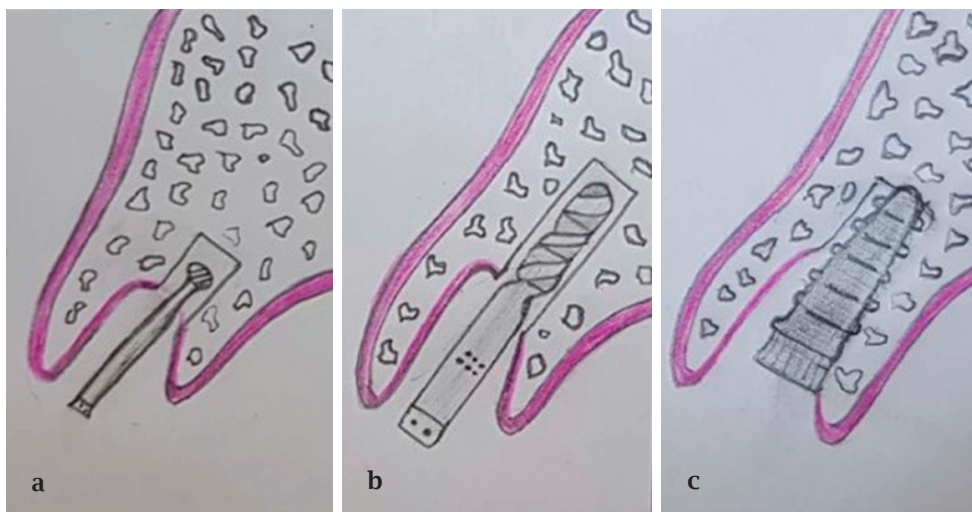

a: Drilling through palatal wall using a bur round; b: Osteotomy site preparation; c: Implant placement. Figure 1: Round bur technique.
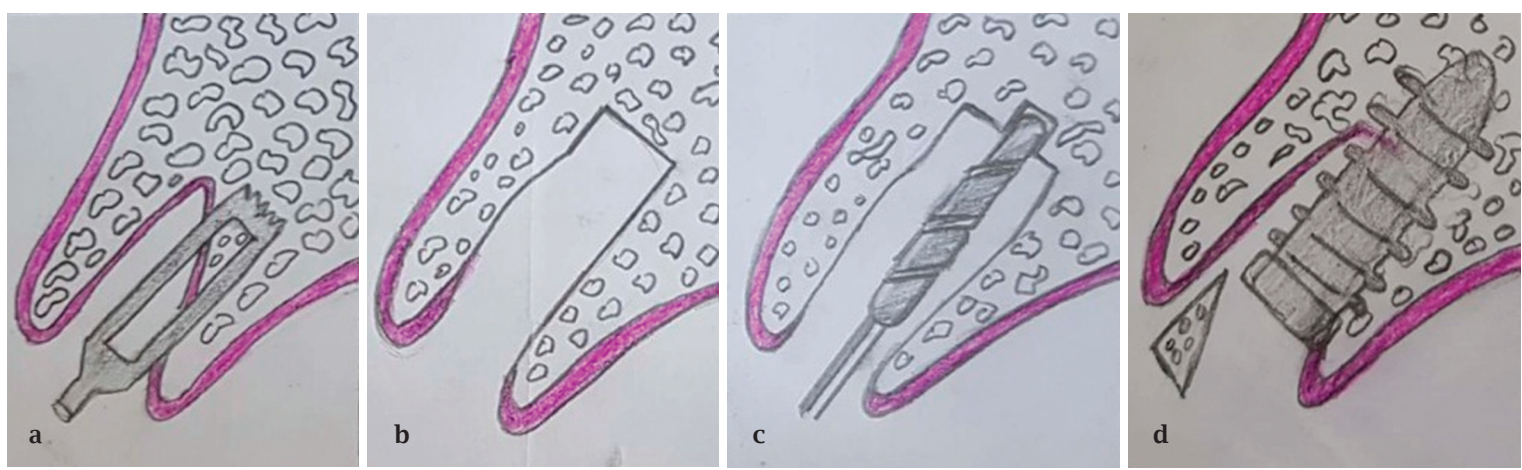

a: Bone graft harvesting using a trephine; b: Extraction socket after bone removal; c: Osteotomy site preparation; d: Implant placement with Bone graft between the implant and buccal bone socket.

Figure 2: Trephine technique. 
2. The trephine technique: allows better axis implant control with recovery of the bone for further filling. Bone graft harvesting using a trephine bur and after placing implant same graft placement can be done between the implant and buccal bone socket. During implant site preparation, the drilling should extend beyond the socket to optimise the implant primary stability.

\section{IMMEDIATE IMPLANT PLACEMENT USING FLAPLESS APPROACH}

The flapless technique provides a minimally invasive approach to extraction with socket grafting or immediate implant placement. Because the interdental papilla remains intact, there is less disruption of blood supply. The flapless approach involves inserting the implant without raising any flaps. It simplifies the procedure, reducing operative time and patient discomfort and favoring acceptance of the implant protocols. ${ }^{54,55}$ However, there are complications such as bony dehiscence and fenestration. A clinical study reports a dehiscence rate of $4.73 \%$ with flapless surgery. ${ }^{56}$ From a biologic point of view, the main advantage of a flapless procedure is preservation of the periosteum and supraperiostal and as a result the blood supply to the alveolar bone is maintained. ${ }^{57,58}$ Some clinical studies suggest that flapless surgery prevents marginal bone loss. ${ }^{59,60}$

\section{SUMMARY}

Immediate implant placement is a reliable technique with implant success rates comparable to those obtained by conventional protocols. It allows a significant comfort to the patient, a reduction of the healing duration and a preservation of the gingival architecture; which optimises the aesthetic outcomes. However proper case selection, diagnosis and treatment planning, clinical expertise, meticulous post-operative care preceded by a good surgical and prosthetic protocol are very essential for the long term success of the immediate implants.

\section{REFERENCES}

1. Schulte W, Heimke G. The Tubinger immediate implant. Quintessenz. 1976;27:17-23.

2. Lazzara RJ. Immediate Implant Placement Into Extraction Socket Sites: Surgical And Restorative Advantages.1989;9(5):332-43.

3. Bornstein MM, Halbritter S, Harnisch H, Weber HP, Buser D. A retrospective analysis of patients referred for implant placement to a specialty clinic regarding indications, surgical procedures and early failures. Int J Oral Maxillofac Implants. 2008;23:1109-16.

4. Brugger OE, Bornstein MM, Kuchler U, Janner SF, Chappuis V, Buser D. Implant therapy in a surgical specialty clinic: an analysis of patients, indications, surgical procedures, risk factors, and early failures. Int J Oral Maxillofac Implants. 2015;30:151-60.

5. Wilson TG, Weber HP. Classification Of And Therapy For Areas Of Deficient Bony Housing Prior To Dental Implant Placement. Int J Periodontics Restorative Dent. 1993;13:451-9.

6. Pal US, Dhiman NK, Singh G, Singh RK, Mohammad S, Malkunje LR. Evaluation Of Implants Placed Immediately Or Delayed Into Extraction Sites. Nat J Maxillofac Surg. 2011;2(1):54-62.

7. Hämmerle $\mathrm{CH}$, Chen ST, Wilson TGJ. Consensus statements and recommended clinical procedures regarding the placement of implants in extraction sockets. Int J Oral Maxillofac Implants. 2004;19 Suppl:26-8.

8. Garber DA, Funato A, Salama MA, Ishikawa T, Salama H. Timing Positioning And Sequential Staging In Esthetic Implant Therapy: A FourDimensional Perspective. Int J Periodont Resto Dent. 2007;27:313-23.

9. Buser D, Chappuis V, Belser UC, Chen S. Implant placement post extraction in esthetic single tooth sites: when immediate, when early, when late? Periodontol 2000. 2017;73:84-102.

10. Broggini N, Cirelli JA. Glossary of oral and maxillofacial implants. Quintessence, 2007.

11. Chen ST, Darby IB, Reynolds EC. Immediate implant placement post extraction without flap elevation. J Periodontol. 2009;80(1):163-72.

12. Araùjo MG, Silva CO, Misawa M, Sukekava F. Alveolar socket healing: what can we learn? Periodontal 2000. 2015;68:122-134.

13. Al Sabbagh M, Kutkut A. Immediate implant placement: Surgical techniques for prevention and management of complications. Dent Clin Am. 2015;59:73-95.

14. Araùjo MG, Lindhe J. Dimensional ridge alterations following tooth extraction. An experimental study in the dog. J Clin Periodontol. 2005;32:212-8.

15. Schropp L, Wenzel A, Kostopoulos L, Karring T. Bone healing and soft tissue contour changes following single-tooth extraction: a clinical and radiographic 12-month prospective study. Int J Perio Rest Dent. 2003;23:313-23.

16. Canullo L, Iurlaro G, Iannello G. Double-blind randomized controlled trial study on post-extraction immediately restored implants using the switching platform concept: soft tissue response. Preliminary report. Clin Oral Implants Res. 2009;20:414-20.

17. Van Kesteren CJ, Schoolfield J, West J, Oates T. A prospective randomized clinical study of changes in soft tissue position following immediate and delayed implant placement. Int J Oral Maxillofac Implants. 2010;25:562-70.

18. Lang NP, Pun L, Lau KY, Li KY, Wong M. A systematic review on survival and success rates of implants placed immediately into fresh extraction sockets after at least 1 year. Clin Oral Implants Res. 2012;23:39-66.

19. Bianchi AE, Sanfilippo F. Single-tooth replacement by immediate implant and connective tissue graft: A 1-9-year clinical evaluation. Clin Oral Implants Res. 2004;15:269-77.

20. Lee C, Tao C, Stoupel J. The Effect of Subepithelial Connective Tissue Graft Placement on Esthetic Outcomes Following Immediate Implant Placement: Systematic Review. J. Periodontol. 2016;87:156-67.

21. Canullo L, Iurlaro G, Iannello G. Double-blind randomized controlled trial study on post-extraction immediately restored implants using the switching platform concept: Soft tissue response. Preliminary report. Clin Oral Implants Res. 2009;20:414-20.

22. Bruno V, O'Sullivan D, Badino M, Catapano S. Preserving soft tissue after placing implants in fresh extraction sockets in the maxillary esthetic zone and a prosthetic template for interim crown fabrication: A prospective study. J Prosthet Dent. 2014;111:195-02. 
23. Bruno V, Badino M, Sacco R, Catapano S. The use of a prosthetic template to maintain the papilla in the esthetic zone for immediate implant placement by means of a radiographic procedure. J Prosthet Dent. 2012;108:394-7.

24. Chen ST, Wilson TG Jr, Hammerle CF. Immediate or early placement of implants following tooth extraction: review of biologic basis, clinical procedures, and outcomes. Consensus statement. Int J Oral Maxillofac Implants. 2004;19:12-25.

25. Mayfield LJ. Immediate, delayed and late submerged and transmucosal implants. In Proceeding of the 3rd European Workshop on Periodontology, 1999 1999. Quintessence.

26. Bhola M, Neely AL, Kolhatkar S. Immediate implant placement: clinical decisions, advantages, and disadvantages. J Prosthodont. 2008; 17:576-81.

27. Esposito M, Grusovin MG, Polyzos IP, Felice P, Worthington HV. Timing of implant placement after tooth extraction: immediate, immediate delayed or delayed implants? A Cochrane systematic review. Eur J Oral Implantol. 2010;3:189-205.

28. Morton D, Chen ST, Martin WC, Levine RA, Buser D. Consensus statements and recommended clinical procedures regarding optimizing esthetic outcomes in implant dentistry. Int J Oral Maxillofac Implants. 2014:29(Suppl):216-20.

29. Kaur G, Tabassum R, Mistry G, Shetty O. Immediate Implant Placement: A Review. J Dent Med Sci. 2017;165:90-5.

30. Sheikh Z, Najeeb S, Khurshid Z, Verma V, Rashid H, Glogauer M. Biodegradable materials for bone repair and tissue engineering applications. Materials. 2015 Sep;8(9):5744-94.

31. Chen ST, Darby IB, Reynolds EC. A prospective clinical study of non-submerged immediate implants: clinical outcomes and esthetic results. Clinical oral implants research. 2007 Oct;18(5):552-62.

32. Le Guéhennec L, Soueidan A, Layrolle P, Amouriq Y. Surface treatments of titanium dental implants for rapid osseointegration. Dental materials. 2007 Jul 1;23(7):844-54.

33. Beagle JR. Surgical Essentials Of Immediate Implant Dentistry. John Wiley \& Sons, Inc. Copyright 2013.

34. Deporter D, Ketabi M. Guidelines for optimizing outcomes with immediate molar implant placement. J Adv Perio Implant Dent. 2017 Oct $31 ; 9(2)$.

35. Mecall RA, Rosenfeld AL. Influence of residual ridge resorption patterns on implant fixture placement and tooth position. Int J Periodontics Restorative Dent. 1991;11(1):8-23.

36. Hurzeler MB, Zuhr O, Schupbach P, Rebele SF, Emmanouilidis N, Fickl S. Socket-shield technique: a proof-of-principlereport. J Clin Periodontol. 2010;37:855-62.

37. Kan JY, Rungcharassaeng K. Proximal socket shield for interimplant papilla preservation in the esthetic zone. Int J Period Resto Dent. 2013;33:24-31.

38. Al-Harbi SA, Edgin WA. Preservation of soft tissue contours with immediate screw-retained provisional implant crown. J Prosthet Dent. 2007;98:329-32.

39. Ntounis A, Petropoulou A. A technique for managing and accurate registration of periimplant soft tissues. J Prosthet Dent. 2010;104:276-9.

40. Schoenbaum TR1, Klokkevold PR, Chang YY Immediate implant-supported provisional restoration with a root-form pontic for the replacement of two adjacent anterior maxillary teeth: A clinical report. J Prosthet Dent. 2013 May;109(5):277-82.

41. Botticelli D, Berglundh T, Buser D, Lindhe J. The jumping distance revisited: An experimental study in the dog. Clin Oral Implants Res. 2003;14(1):35-42.

42. Januário AL, Duarte WR, Barriviera M, Mesti JC, Araújo MG, Lindhe J. Dimension of the facial bone wall in the anterior maxilla: A conebeam computed tomography study. Clin Oral Implants Res. 2011;22(10):1168-71.

43. Katranji A, Misch K, Wang HL. Cortical bone thickness in dentate and edentulous human cadavers. J Periodontol. 2007;78(5):874-8.

44. Chen ST, Darby IB, Reynolds EC. A prospective clinical study of non-submerged immediate implants: Clinical outcomes and esthetic results. Clin Oral Implants Res. 2007;18(5):552-62.

45. Greenstein G, Cavallaro J. Managing the buccal gap and plate of bone: Immediate dental implant placement. Dent Today. 2013;32(3):70-2.

46. Matarasso S, Salvi GE, Iorio Siciliano V, Cafiero C, Blasi A, Lang NP. Dimensional ridge alterations following immediate implant placement in molar extraction sites: a six-month prospective cohort study with surgical re-entry. Clin Oral Implants Res. 2009;20: 1092-8.

47. Siciliano VI, Salvi GE, Matarasso S, Cafiero C, Blasi A, Lang NP. Soft tissues healing at immediate transmucosal implants placed into molar extraction sites with buccal self-contained dehiscences. A 12-month controlled clinical trial. Clin Oral Implants Res. 2009;20:482-8.

48. Schropp L, Isidor F. Timing of implant placement relative to tooth extraction. J Oral Rehabil. 2008;35:33-43.

49. Araujo MG, Lindhe J. Socket grafting with the use of autologous bone: an experimental study in the dog. Clin Oral Impl Res. $2011 ; 22: 9-13$.

50. Bhola M, Neely AL, Kolhatkar S. Immediate implant placement: clinical decisions, advantages, and disadvantages. J Prosthodont. 2008; $17: 576-81$.

51. Alves CC, Correia AR, Neves M. Immediate implants and immediate loading in periodontally compromised patients-a 3-year prospective clinical study. Int J Periodontics Restorative Dent. 2010;30:447-55.

52. Deng F, Zhang H, Zhang H, Shao H, He Q, Zhang P. A comparison of clinical outcomes for implants placed in fresh extraction sockets versus healed sites in periodontally compromised patients: a 1-year follow-up report. Int J Oral Maxillofac Implants. 2010; 25:1036-40.

53. Amine M, EI Kholti W, Laalou Y, Bennani A, Kissa J. Immediate Implant Placement: A Review. Journal of Dentistry Forecast. 2018;1:2:1-5.

54. Lin GH, Chan HL, Bashutski JD, Oh TJ, Wang HL. The effect of flapless surgery on implant survival and marginal bone level: a systematic review and meta-analysis. J Periodontol. 2014:8:91-103.

55. Arisan V, Karabuda CZ, Ozdemir T. Implant surgery using bone- and mucosa-supported stereolithographic guides in totally edentulous jaws: surgical and post-operative outcomes of computer-aided vs standard techniques. Clin Oral Implants Res. 2010:21: 980-8.

56. Campelo LD, Camara JR. Flapless implant surgery: a 10-year clinical retrospective analysis. Int J Oral Maxillofac Implants. 2002:17:271-6.

57. Costich ER, Ramfjord SP. Healing after partial denudation of the alveolar process. J Periodontol. 1968;39:127-34

58. Staffileno H. Significant differences and advantages between the full thickness and split thickness flaps. J Periodontol. 1974;45:421-5.

59. Rocci A, Martignoni M, Gottlow J. Immediate loading in the maxilla using flapless surgery, implants placed in predetermined positions, and prefabricated provisional restorations: a retrospective 3-year clinical study. Clin Implant Dent Relat Res. 2003:5 (Suppl. 1):29-36.

60. Becker W, Goldstein M, Becker BE, Sennerby L. Minimally invasive flapless implant surgery: a prospective multicenter study. Clin Implant Dent Relat Res. 2005:7(Suppl.1): 21-27. 